\title{
POTENSI BATUGAMPING UNTUK BAHAN BAKU INDUSTRI SEMEN DAERAH BILUHU TIMUR DAN SEKITARNYA
}

\author{
Destira Handayani Eksan ${ }^{\mathrm{a}}$, Ahmad Zainuri ${ }^{\mathrm{a}}$, Muhammad Kasim ${ }^{\mathrm{a}}$ \\ a Teknik Geologi, Universitas Negeri Gorontalo, Jl. Jendral Sudirman, No. 6, Kota Gorontalo, 96128, Indonesia
}

\section{INFO ARTIKEL}

\section{Status artikel:}

Diterima: 2 Juli 2019

Disetujui: 15 Juli 2019

Tersedia online: 22 Juli 2019

\section{Kata kunci:}

Biluhu Timur; Cement; Limestone; Resources; XRF

\section{Penulis korespondensi:}

Destira Handayani Eksan

Program Studi Teknik Geologi, Jurusan Ilmu dan Teknologi Kebumian, Fakultas Matematika dan IPA, Universitas Negeri Gorontalo, Kota Gorontalo, Indonesia Email: destira.h.eksan@gmail.com

\begin{abstract}
Limestone is a sedimentary rock composed by calcium carbonate derived from the rest of marine organisms and the main materials of cement so exploration and calculation of limestone resources need to be done. The research area is administratively located at the Biluhu Timur Village and its surroundings, Batudaa Pantai District, Gorontalo Regency. The purpose of this study is to observe the geological conditions of the study area to determine distribution of limestones in the study area to be used as cement industrial materials with the geological mapping, and the analysis limestone geochemical using XRF (X-Ray Flourescence). Based on the result of this research can be concluded that the research area was devided into four geomorphological units, consisting of volcanic hills unit, denudational hills and plain unit, and the coastal plain unit. The litology arranged by granodiorit, basal, and the limestone (packstone and wackestone). Based on the result of geochemical analysis using XRF and calculation of volume using Surpac softwere can be devided into three blocks. The A block have limestones (packstone) with the content of $\mathrm{CaO} 51.79 \%$ and $\mathrm{MgO} 1.98 \%$ that meets the requirement materials of portland cement with total volume 423107230 tons. The B block have limestones (wackestone) with the content of $\mathrm{CaO} 4.92 \%$ and $\mathrm{MgO} 5.28 \%$ that not meets the requirement materials of portland cement with total volume 729263008 tons. The C block have limestones (packstone) with the content of $\mathrm{CaO} 52.85 \%$ and $\mathrm{MgO} 0.98 \%$ that meets the requirement materials of portland cement with total volume 539883 150 tons.
\end{abstract}

Copyright (C) 2019 JGeosREV-UNG This open access article is distributed under a Creative Commons Attribution (CC-BY) 4.0 International license

\section{Pendahuluan}

Pulau Sulawesi disusun oleh berbagai formasi batuan yang meliputi batuan beku, sedimen, hingga batuan metamorf. Salah satu jenis batuan sedimen yang terdapat di Pulau Sulawesi adalah batugamping. Batugamping di Pulau Sulawesi tersebar di berbagai daerah. Sumber daya batugamping yang tersebar hampir di semua Provinsi yang terdapat di Pulau Sulawesi juga telah banyak yang dimanfaatkan baik sebagai bahan baku semen ataupun bahan baku industri lainnya. Provinsi Gorontalo merupakan salah satu provinsi yang memiliki sumber daya batugamping di Pulau Sulawesi (Sukhyar et al., 2012)

Provinsi Gorontalo memiliki sumber daya batugamping yang cukup besar dan sebagian telah dimanfaatkan oleh masyarakat sebagai bahan baku pembuatan kapur. Banyak terdapat lokasi-lokasi galian batugamping yang dikelola oleh masyarakat. Salah satu daerah yang memiliki sumber daya batugamping yang cukup besar di Gorontalo yakni Kecamatan Batudaa Pantai, namun batugamping yang terdapat di Kecamatan Batudaa Pantai belum termanfaatkan secara optimal. Menurut data BPS (2018), di Kecamatan Batudaa Pantai belum terdapat kegiatan penambangan batugamping ataupun pemanfaatannya sebagai bahan baku industri lainnya.

Daerah penelitian secara administratif terletak di Kecamatan Batudaa Pantai, yang meliputi Desa Biluhu, Desa Kayubulan, serta Desa Lopo Kabupaten Gorontalo Provinsi Gorontalo, tepatnya berada

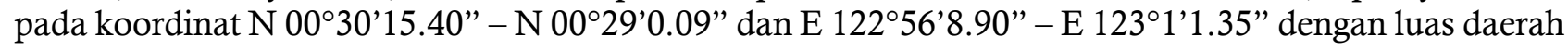


penelitian $20.91 \mathrm{Km}^{2}$ (Gambar 1). Wilayah penelitian dapat dicapai dari Kota Gorontalo menggunakan kendaraan beroda dua dan beroda empat sejauh $17.4 \mathrm{~km}$ dari Kota Gorontalo dengan waktu tempuh sekitar 47 menit perjalanan. Tujuan dari penelitian ini yakni untuk mengamati kondisi geologi daerah penelitian untuk mengetahui sebaran batugamping yang ada di daerah penelitian dengan melakukan pemetaan geologi permukaan, serta potensi sumber daya batugamping dengan melakukan analisis geokimia batugamping untuk megetahui besarnya kandungan $\mathrm{CaO}$ pada batugamping untuk dapat dimanfaatkan sebagai bahan baku industri semen.

\section{Metodologi}

Metode yang digunakan dalam penelitian ini yaitu dengan cara survei lapangan berupa pemetaan geologi permukaan dan analisis laboratorium. Pemetaan geologi permukaan ini berupa observasi lapangan dengan mengamati sebaran litologi daerah penelitan khususnya batugamping serta pengambilan contoh batuan yang selanjutnya akan dilakukan analisa di laboratorium dengan menganalisis kandungan kimia pada sampel dengan menggunakan alat X-Ray Fluorescence (XRF), serta analisis petrografi berupa pengamatan sayatan tipis batuan.

\subsection{Tahap Persiapan}

Persiapan alat dan bahan yang akan dipakai pada saat penelitian berlangsung. Adapun alat dan bahan yang digunakan pada penelitian ini merupakan peralatan lapangan berupa GPS (Global Positioning Satellites) garmin, palu geologi, kompas geologi tipe brunton, komparator mineral dan besar butir, loupe perbesaran $30 \times 60$, kamera digital, kantong sampel, HCL, alat tulis menulis, peta topografi daerah penelitian dengan skala 1:25000 (BIG, 2013), tas ransel serta peralatan lapangan pendukung lain. Selain itu pada tahapan ini dilakukan juga perencanaan kerja berupa perizinan melakukan penelitian pada lokasi penelitian.

Pada tahapan ini dilakukan studi literatur untuk memperoleh gambaran umum keadaan geologi daerah penelitian secara regional. Dapat berupa buku, artikel, serta hasil penelitian terdahulu, sehingga didapatkan data sekunder mengenai kondisi geologi yang berhubungan dengan daerah penelitian. Pada tahapan ini juga termasuk pembuatan peta dasar daerah penelitian berupa peta geologi dan geomorfologi tentatif, pola aliran sungai, dan peta geologi regional.

\subsection{Tahap Penelitian Lapangan}

Tahap ini dilakukan untuk mengetahui tatanan geologi di daerah penelitian yang meliputi: observasi geomorfologi, litologi dan pengukuran unsur-unsur struktur geologi dan pengambilan sampel untuk analisis pada laboratorium.

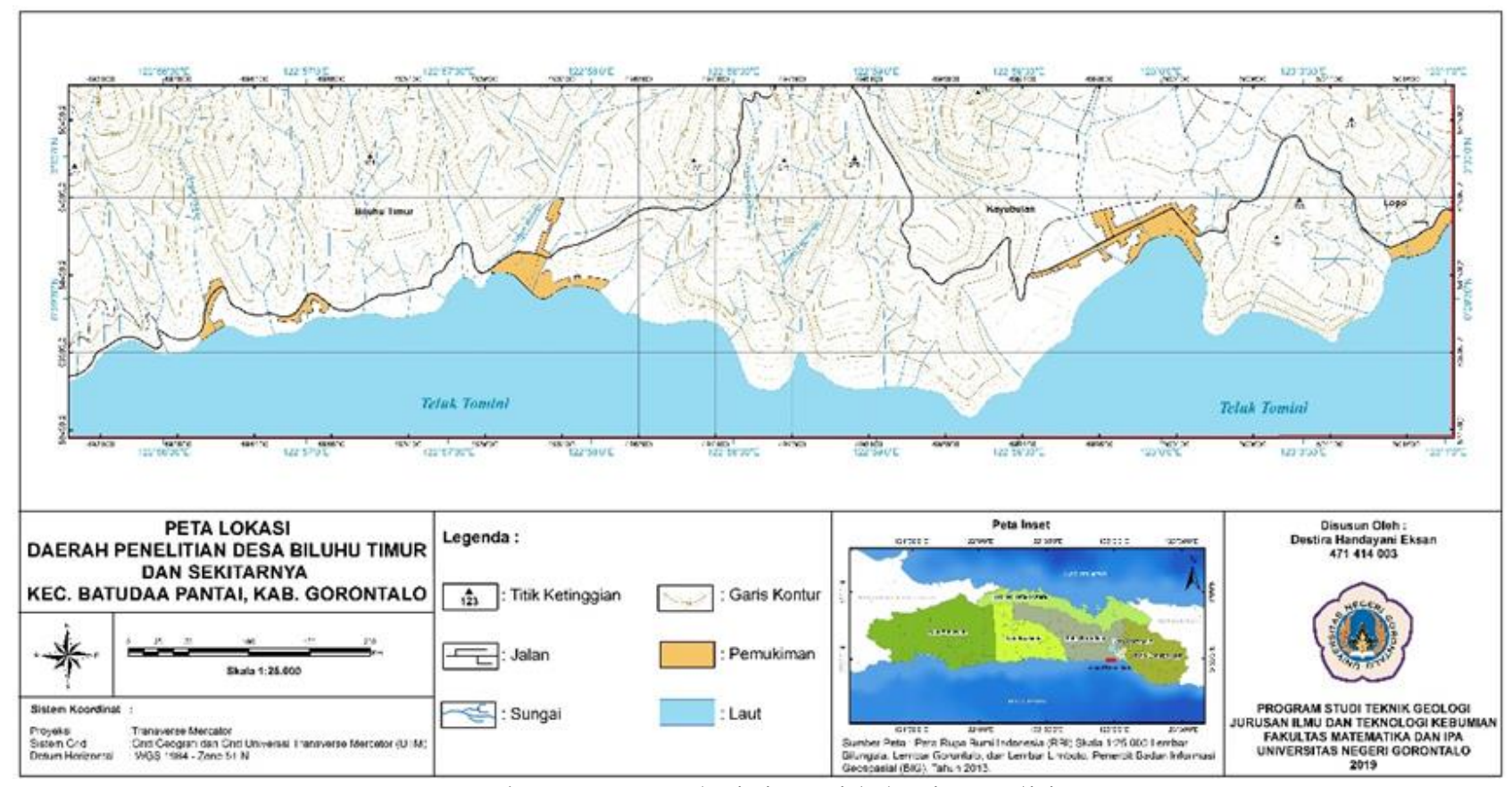

Gambar 1. Peta administrasi lokasi penelitian 


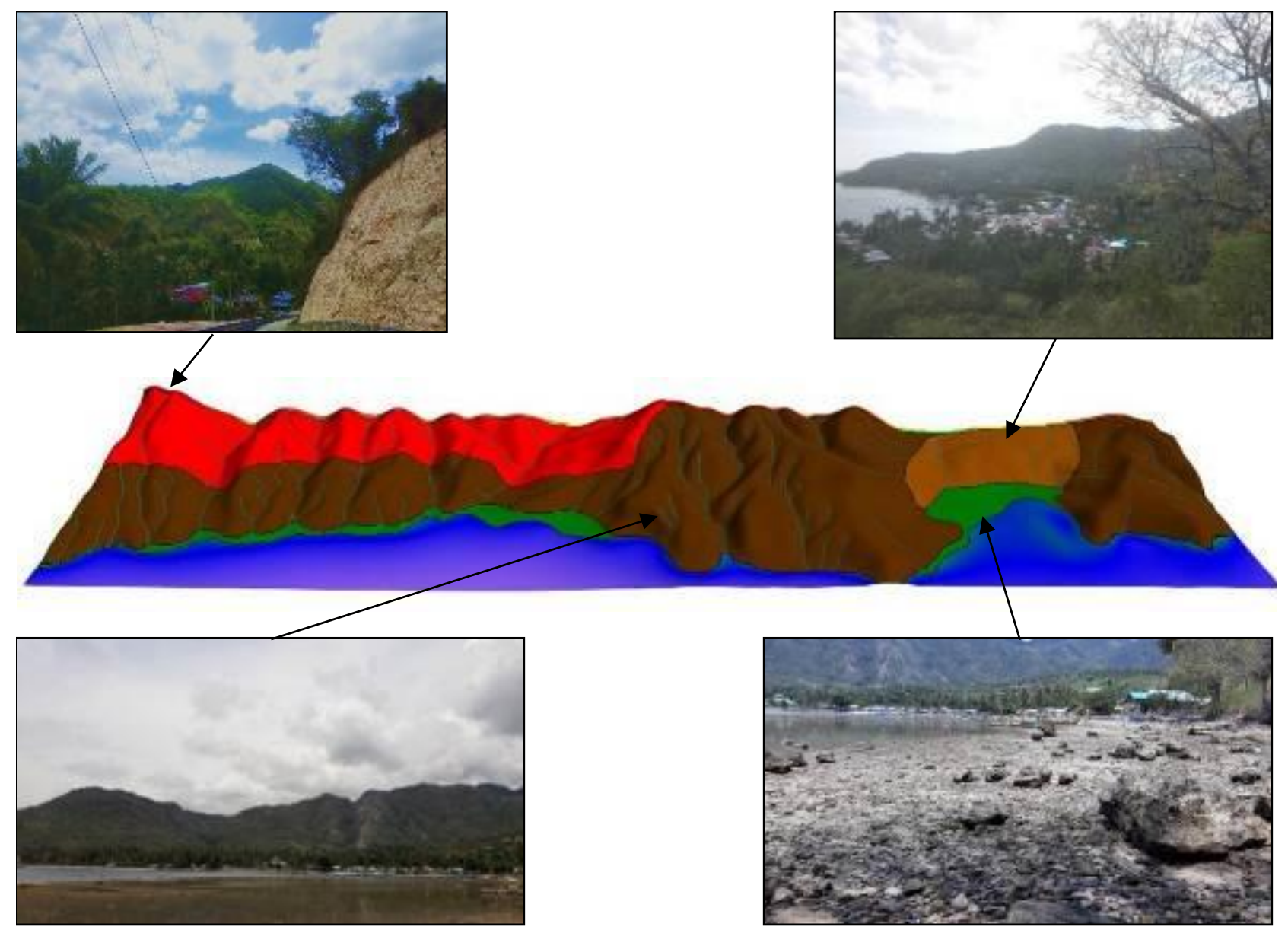

Gambar 2. Satuan Geomorfologi pada daerah penelitian (tanpa skala). Satuan perbukitan vulkanik Biluhu berwarna merah, satuan perbukitan denudasional Batudaa Pantai berwarna coklat tua, satuan dataran denudasional Kayubulan berwarna coklat muda, dan satuan dataran marin Batudaa Pantai berwarna hijau

\subsection{Tahap Analisis dan Pengolahan Data}

Tahap analisis dan pengolahan data dilakukan di laboratorium dan studio. Analisis laboratorium yang dilakukan adalah analisis petrologi, petrografi, struktur geologi dan analisis kimia menggunakan XRF. Pengolahan data yang dilakukan di studio meliputi pembuatan peta lintasan pengamatan, peta geomorfologi, peta geologi daerah penelitian dengan skala 1:25.000 serta peta sebaran sumberdaya batugamping. Kegiatan ini dilakukan dengan menggunakan softwere Streonet 10.1.4, Diagram Roset 3.0, Surpac 6.4.1, dan ArcGIS 10.3.

\section{Hasil dan Pembahasan}

\subsection{Geologi Daerah Penelitian}

Geomorfologi daerah penelitian terdiri dari empat satuan geomorfologi berdasarkan klasifikasi Van Zuidam (1983) yang dapat dibedakan berdasarkan data yang diperoleh dari analisa topografi dan hasil pengamatan langsung di lapangan, dengan memperhatikan bentuk lahan (morfologi), kelerengan (morfometri), jenis litologi penyusun dan struktur geologi (morfostruktur pasif) dan proses-proses geologi (morfostruktur aktif) (Tabel 1) yakni, satuan perbukitan vulkanik Biluhu, satuan perbukitan denudasional Batudaa Pantai, satuan dataran denudasional kayubulan, serta satuan endapan pantai Batudaa Pantai (Gambar 2).

Stratigrafi daerah penelitian berdasarkan hasil analisis laboratorium dan pengamatan lapangan didapatkan empat jenis satuan litologi yang terdiri dari satuan basal berumur Eosen, satuan granodiorit berumur Miosen, dan satuan batugamping terumbu serta endapan pantai berumur Holosen. Penyusunan satuan sratigrafi pada daerah penelitian menggunakan sistem penamaan tidak resmi yang didasarkan pada kesamaan ciri litologi yang terdapat pada daerah penelitian (Tabel 2). 
Tabel 1. Karakteristik geomorfologi daerah penelitian

\begin{tabular}{|c|c|c|c|c|c|c|}
\hline \multirow{2}{*}{\multicolumn{3}{|c|}{ Aspek Geomorfologi }} & \multicolumn{4}{|c|}{ Satuan Geomorfologi } \\
\hline & & & Dataran Pantai & Dataran Denudasional & Perbukitan Denudasional & Perbukitan Vulkanik \\
\hline \multirow{6}{*}{$\begin{array}{l}\text { कृ } \\
\text { 을 } \\
\text { tั } \\
\Sigma\end{array}$} & & Morfografi & Dataran & Dataran & Perbukitan & Perbukitan \\
\hline & \multirow{5}{*}{ 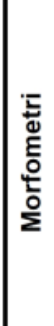 } & Lereng & $\begin{array}{l}\text { Umumnya datar - hampir } \\
\text { datar }\end{array}$ & $\begin{array}{l}\text { Umumnya datar - hampir } \\
\text { datar }\end{array}$ & $\begin{array}{l}\text { Umumnya curam - sangat } \\
\text { curam }\end{array}$ & $\begin{array}{l}\text { Umumnya curam - sangat } \\
\text { curam }\end{array}$ \\
\hline & & Pola Lereng & Relatif ke arah selatan & Relatif ke arah selatan & Relatif ke arah selatan & Relatif ke arah selatan \\
\hline & & Kelas Relief & Datar & Berbukit & Berbukit & Berbukit \\
\hline & & Pola Aliran & Paralel & Paralel & Paralel & Paralel \\
\hline & & $\begin{array}{l}\text { Bentuk } \\
\text { Lembah }\end{array}$ & $u$ & $\mathrm{~V}-\mathrm{U}$ & $\mathrm{V}-\mathrm{U}$ & $\mathrm{V}-\mathrm{U}$ \\
\hline \multirow{2}{*}{ 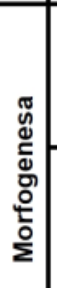 } & & $\begin{array}{l}\text { Morfostruktur } \\
\text { Aktif }\end{array}$ & - & - & $\begin{array}{l}\text { Terkekarkan dan } \\
\text { tersesarkan berarah } \\
\text { barat laut - tenggara dan } \\
\text { timur laut - barat daya }\end{array}$ & $\begin{array}{l}\text { Terkekarkan dan } \\
\text { tersesarkan berarah } \\
\text { barat laut-tenggara }\end{array}$ \\
\hline & & $\begin{array}{l}\text { Morfostruktur } \\
\text { Pasif }\end{array}$ & $\begin{array}{l}\text { Didominasi oleh } \\
\text { endapan sedimen } \\
\text { laut berukuran } \\
\text { pasir - kerakal }\end{array}$ & $\begin{array}{l}\text { Didominasi oleh } \\
\text { batugamping }\end{array}$ & $\begin{array}{l}\text { Didominasi oleh } \\
\text { batugamping }\end{array}$ & $\begin{array}{l}\text { Didominasi oleh } \\
\text { basal dan } \\
\text { granodiorit }\end{array}$ \\
\hline
\end{tabular}

Tabel 2. Stratigrafi daerah penelitian

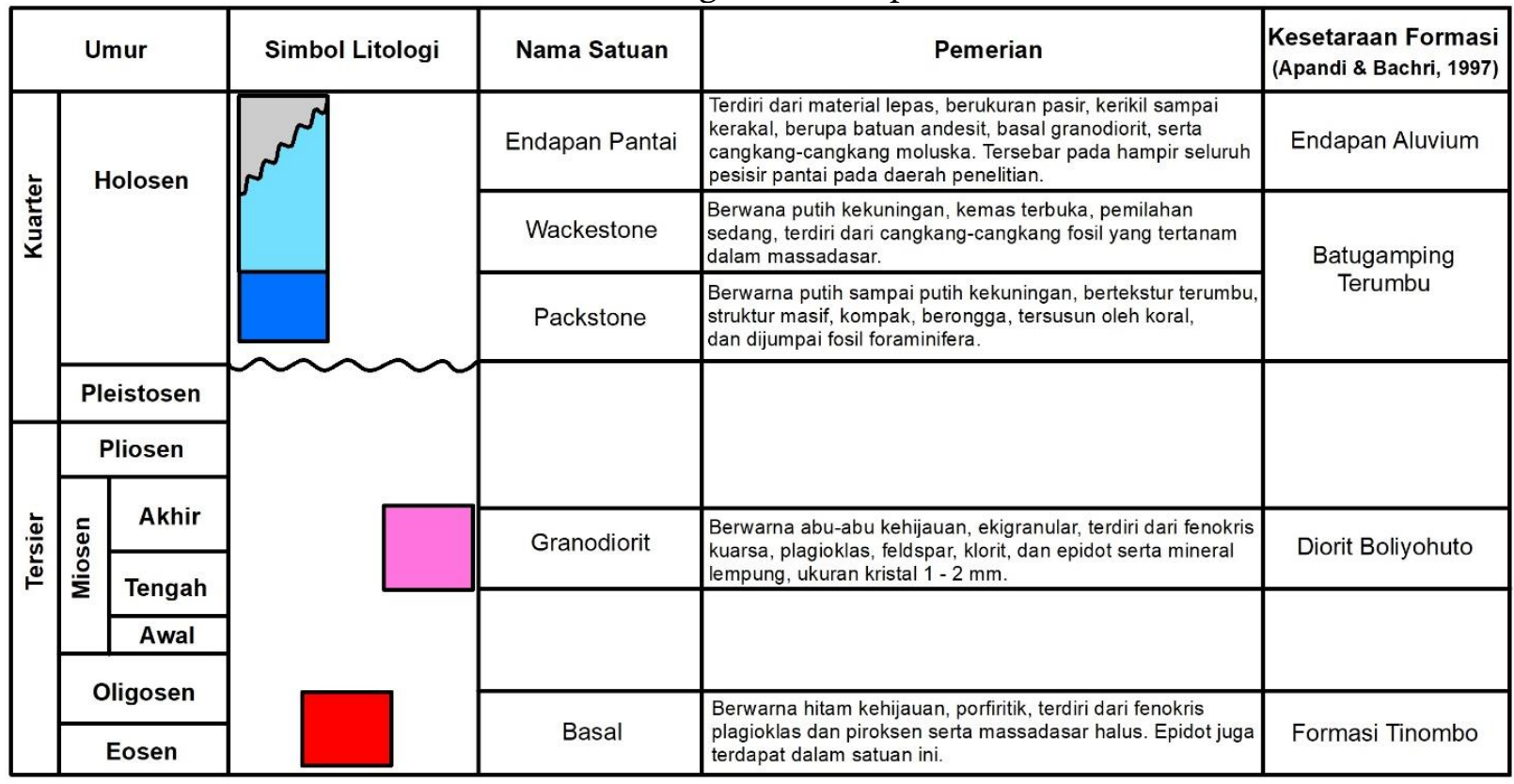

Satuan basal dicirikan berwarna hitam kehijauan dengan tekstur porfiritik yang terdiri dari fenokris berupa plagioklas dan piroksen serta mempunyai massadasar afanitik gelas vulkanik, epidot dan klorit juga tampak pada satuan ini (Gambar 3). Satuan ini menempati sekitar 10\% dari luas daerah penelitian dan tersebar di bagian utara membentang dari arah barat hingga hampir tengah daerah penelitian (Gambar 8). Satuan granodiorit berwarna dicirikan abu-abu kehijauan dengan tekstur ekigranular yang terdiri dari fenokris berupa kuarsa, plagioklas, feldspar, klorit dan epidot serta mineral lempung (Gambar 4). Satuan ini menempati sekitar $10 \%$ dari luas keseluruhan daerah penelitian dan tersebar di bagian tengah utara daerah penelitian (Gambar 8).

Satuan batugamping terumbu pada lokasi penelitian terbagi atas dua jenis batuamping yakni, packstone dan wackestone (Dunham, 1962), yang dapat dibedakan berdasarkan ciri fisik. Satuan batugamping (packstone) dicirikan dengan memperlihatkan komponen terbanyak yaitu cangkang - cangkang foraminifera, putih ke abu-abuan, kompak, komponen utama koral, semen karbonatan, dan mineral kalsit. Sebagian besar cangkang fosil telah mengalami mikritisasi, dan mikrosparit serta sparit hadir sebagai massadasar yang bersifat lebih terang dari pada mikrit (Gambar 5). Penyebaran satuan ini sekitar $25 \%$ dari luas keseluruhan lokasi penelitian. Satuan batugamping (wackestone) dicirikan dengan cangkang-cangkang fosil yang tertanam dalam massadasar, warna putih kekuningan, setempat didapati 

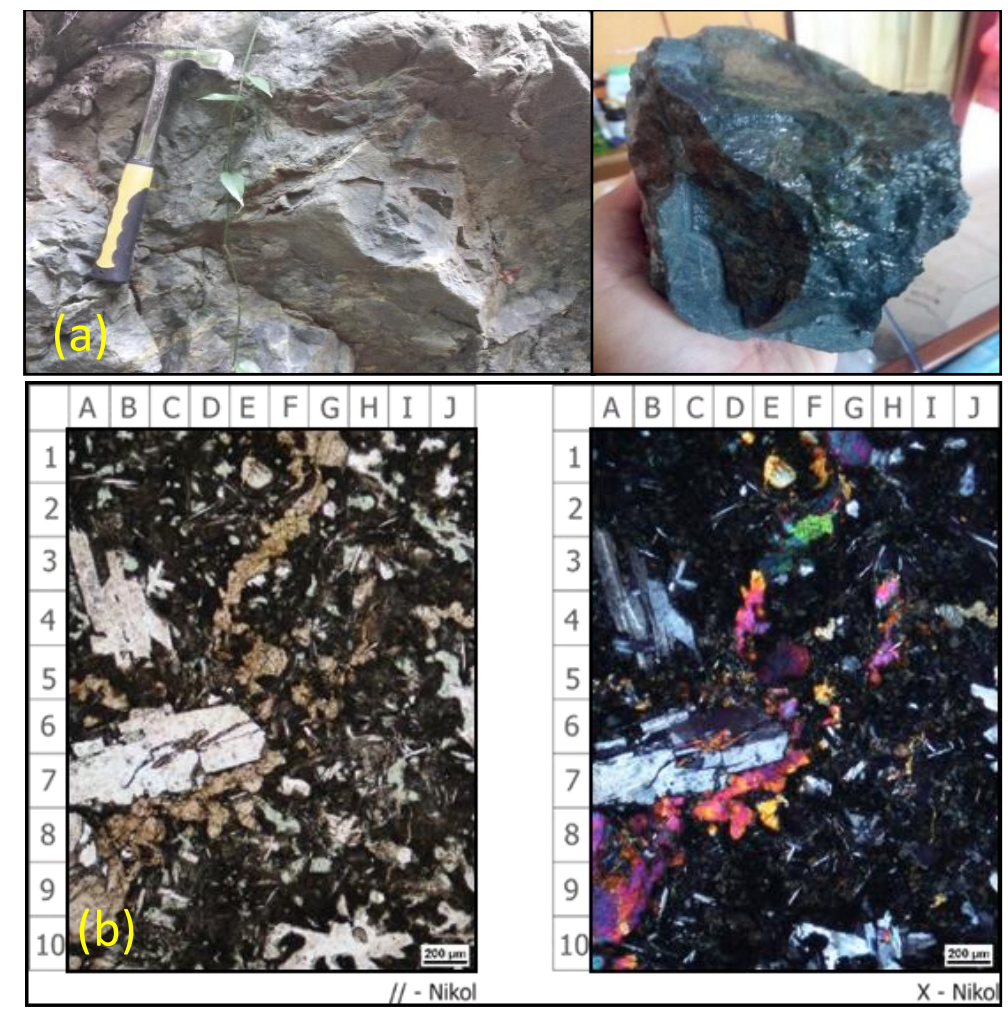

Gambar 3. (a) singkapan, hand speciment, dan (b) foto mikroskopis satuan basal

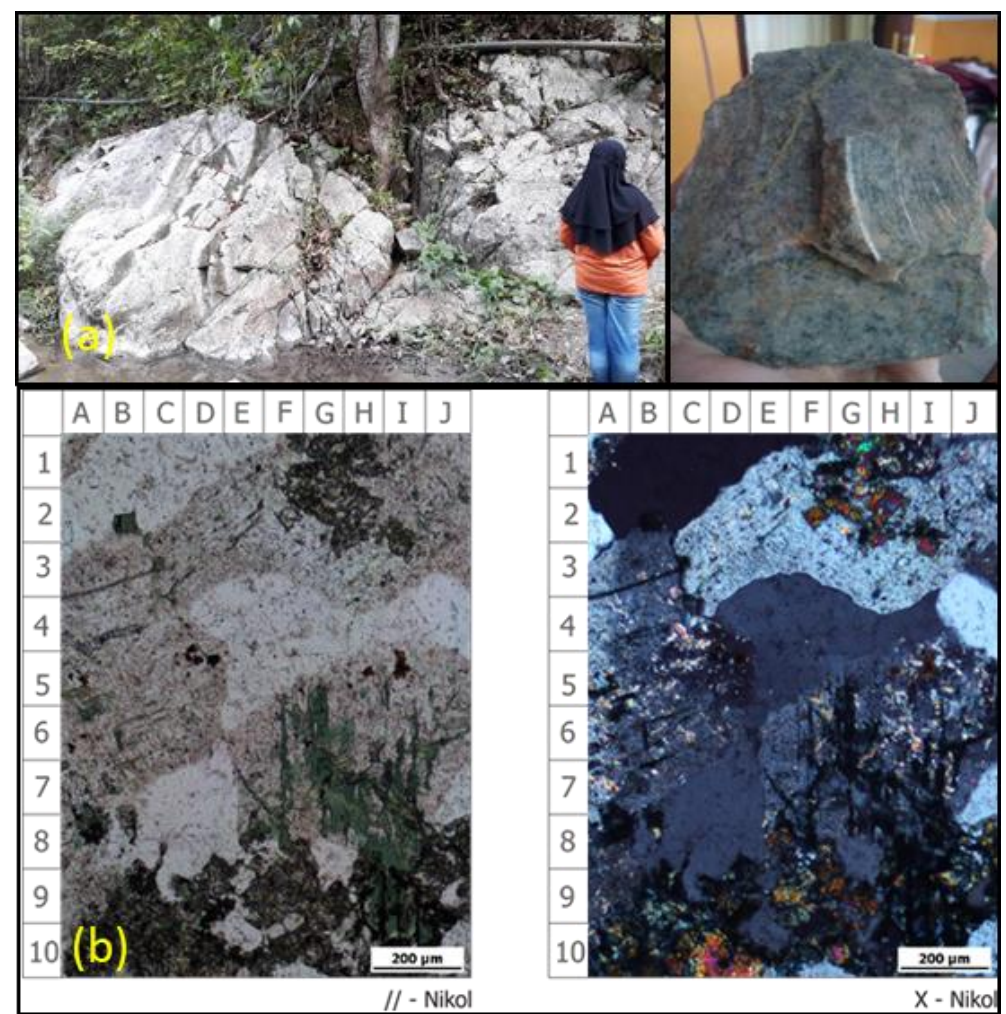

Gambar 4. (a) singkapan, hand speciment, dan (b) foto mikroskopis satuan granodiorit

sudah mengalami pelapukan, mineral kalsit, semen karbonatan serta sebagian cangkang fosil telah mengalami mikritisasi (Gambar 6). Satuan ini menempati 40\% dari total luas keseluruhan lokasi penelitian, singkapan batuan ini dapat dijumpai disepanjang pesisir pantai di daerah Lopo dan sebagian Biluhu Timur (Gambar 8).

Satuan yang terakhir yakni satuan endapan pantai yang terendapkan tidak selaras diatas satuan batugamping terumbu, dicirikan dengan material lepas berukuran kerikil sampai kerakal yang terdiri dari batuan basal, granodiorit, andesit, batugamping, serta cangkang kerang dan terumbu karang yang telah mati (Gambar 7). Satuan ini menempati 5\% dari keseluruhan luas lokasi penelitian (Gambar 8). 


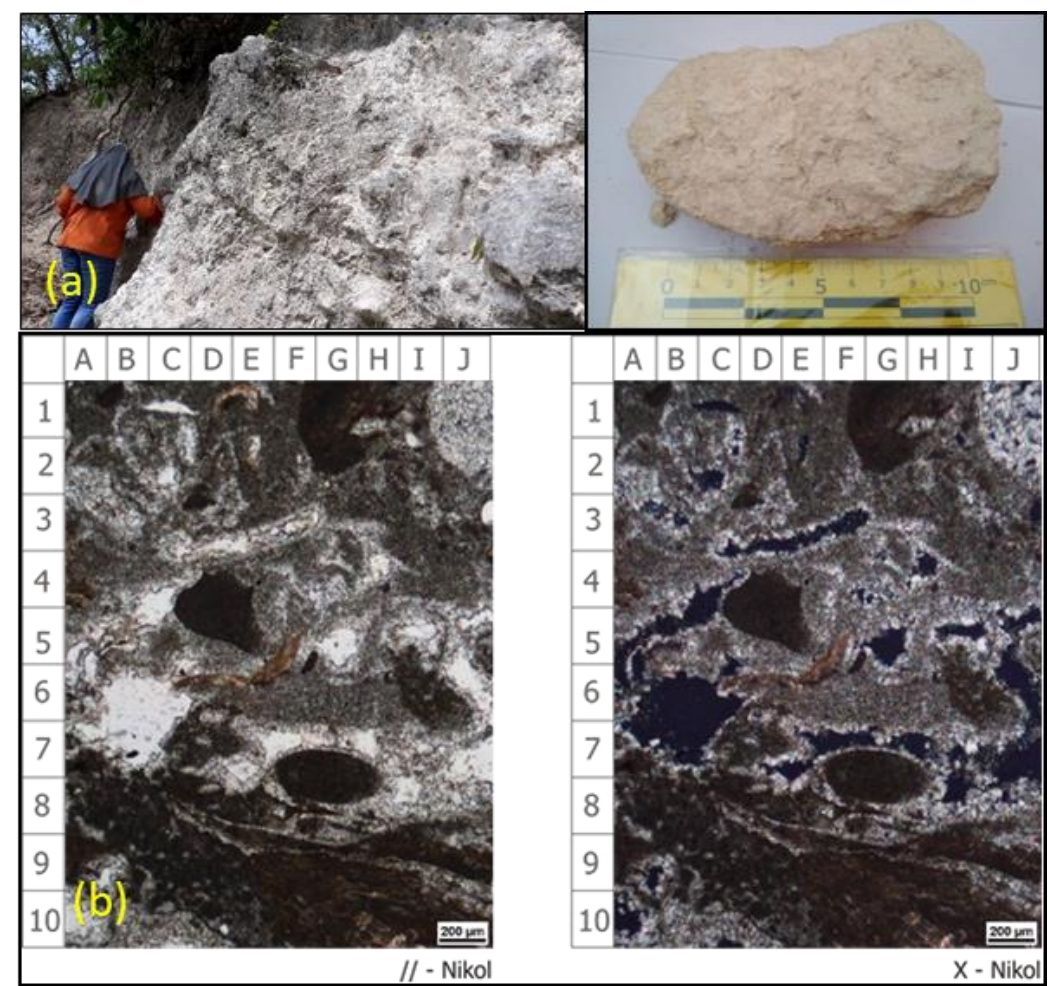

Gambar 5. (a) singkapan, hand speciment, dan (b) foto mikroskopis satuan packstone

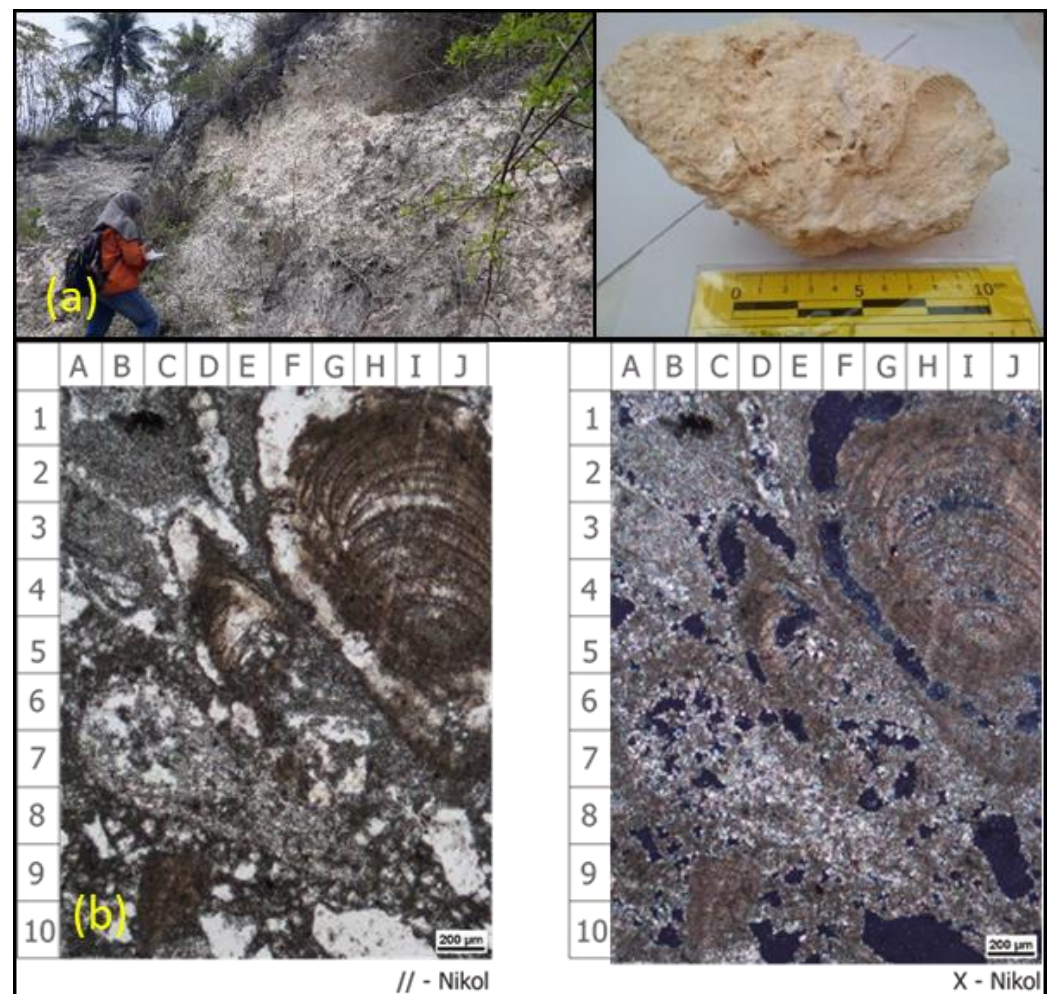

Gambar 6. (a) singkapan, hand speciment, dan (b) foto mikroskopis satuan wackstone

\subsection{Perbedaan Berdasarkan Sifat Kimia}

Analisis geokimia batugamping dilakukan dengan menggunakan XRF (X-Ray Fluoresence). Analisis ini dilakukan pada 3 contoh yaitu sampel pada stasiun DT.1, DT.17, dan DT.26 (Tabel 3). Contoh sampel DT.1 dan D.26 merupakan hasil analisis untuk batugamping berjenis packstone yang ditandai warna biru tua pada peta geologi (Gambar 8), sedangkan sampel DT.17 merupakan contoh batugamping berjenis wackstone berwarna biru muda pada peta geologi (Gambar 8). Terlihat perbedaan pada kandungan $\mathrm{CaO}$ pada dua jenis batugamping yang telah diuji. Hasil analisis kandungan $\mathrm{CaO}$ pada batugamping jenis packstone $>50 \%$. Berdasarkan SNI 7574:2010, kandungan $\mathrm{CaO}$ untuk dimanfaatkan sebagai bahan baku semen memiliki kandungan $>50 \%$, dan kandungan $\mathrm{MgO}<2 \%(\mathrm{BSN}, 2010)$. 


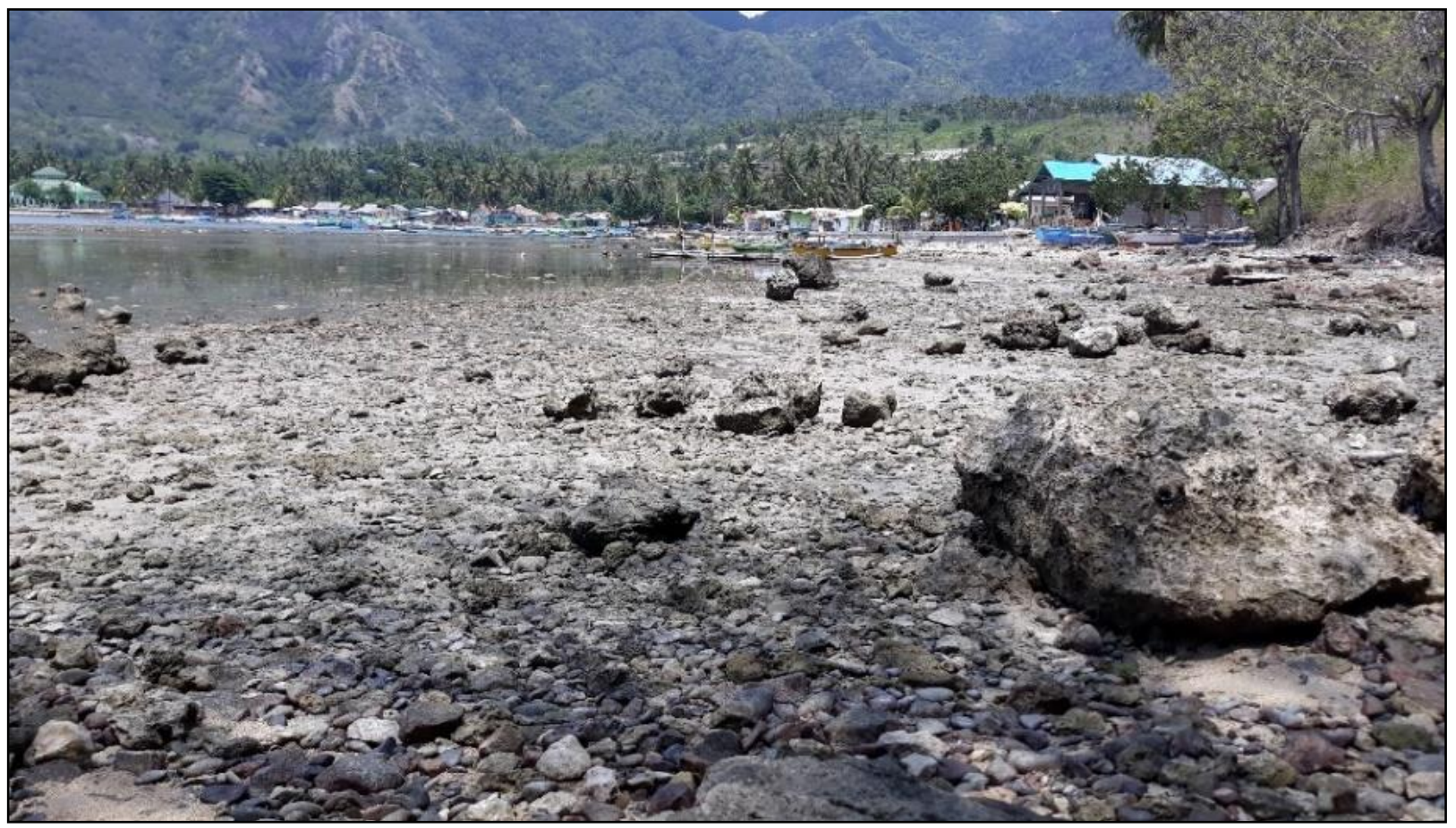

Gambar 7. Material - material lepas yang disusun oleh litologi basal, granodiorit, andesit, breksi dan batugamping di Desa Kayubulan

Kandungan $\mathrm{CaO}$ pada daerah penelitian sebesar 51.79 dan 52.85\%, serta kandungan $\mathrm{MgO}$ sebesar $1.98 \%$ dan $0.97 \%$ terdapat pada contoh sampel batugamping jenis packstone, sedangkan jenis batugamping wackstone memiliki kandungan $\mathrm{CaO}$ sebesar 46.92\% dan $\mathrm{MgO}$ 5.28\%. Dapat disimpulkan batugamping di daerah penelitian yang dapat digunakan sebagai bahan baku semen yaitu batugamping jenis packstone.

\subsection{Pemanfaatan Batugamping Unuk Bahan Baku Semen}

Dalam pembuatan semen, batugamping merupakan bahan baku utama. Selain batugamping, dibutuhkan juga bahan baku lain seperti lempung, pasir kuarsa, dan gypsum serta pasir besi. Semen Portland adalah semen yang tersusun oleh senyawa - senyawa utama $\mathrm{CaO}$, $\mathrm{SiO} 2, \mathrm{Al} 2 \mathrm{O} 3$, dan $\mathrm{Fe} 2 \mathrm{O} 3$ yang dapat diperoleh dari bebagai sumber bahan (Tarmiji, dalam Sukandarrumidi, 2009).

Terdapat syarat tertentu agar batugamping dapat digunakan sebagai bahan baku semen. Syarat tersebut tidak selalu sama untuk setiap pabrik. Namun perbedaan syarat utama untuk komposisi kimia dari batugamping sebagai bahan baku utamanya tidaklah terlalu besar. Berdasarkan Standar Nasional Indonesia (SNI) kandungan minimal $\mathrm{CaO}$ untuk pembuatan semen adalah harus lebih dari 50\%, dan berdasarkan Standar Industri Indonesia, kadar $\mathrm{CaO} \geq 50 \%$ serta kadar $\mathrm{MgO}<5 \%$. Kadar Cao $>50 \%$ dan kandungan $\mathrm{MgO}<2 \%$ pada batugamping jenis packstone pada daerah penelitian termasuk kedalam kategori Semen Portland Tipe I berdasarkan klasifikasi ASTM C150 (2014) yang merupakan semen Portland biasa yang tidak memerlukan persyaratan khusus dalam pengerjaannya, serta memenuhi kriteria berdasarkan SNI untuk standar $\mathrm{CaO}$ dan $\mathrm{MgO}$.

Tabel 3. Hasil analisis geokimia batugamping pada daerah penelitian

\begin{tabular}{llll}
\hline Parameter & DT. 1 & DT. 17 & DT. 26 \\
\hline $\mathrm{SiO}_{2}$ & 1.87 & 3.78 & 1.77 \\
$\mathrm{Al}_{2} \mathrm{O}_{3}$ & 0.62 & 1.04 & 1.03 \\
$\mathrm{Fe}_{2} \mathrm{O}_{3}$ & 0.14 & 0.13 & 0.02 \\
$\mathbf{C a O}$ & $\mathbf{5 1 . 7 9}$ & $\mathbf{4 6 . 9 2}$ & $\mathbf{5 2 . 8 5}$ \\
$\mathbf{M g O}$ & $\mathbf{1 . 9 8}$ & $\mathbf{5 . 2 8}$ & $\mathbf{0 . 9 7}$ \\
$\mathrm{Na}$ & 0.39 & 0.13 & 0.09 \\
$\mathrm{~K}_{2} \mathrm{O}$ & 0.06 & 0.06 & 0.03 \\
$\mathrm{TiO}_{2}$ & 0.01 & 0.02 & 0.01 \\
$\mathrm{MnO}$ & 0.01 & 0.02 & 0.01 \\
$\mathrm{P}_{2} \mathrm{O}_{5}$ & 0.01 & 0.01 & 0.01 \\
\hline
\end{tabular}




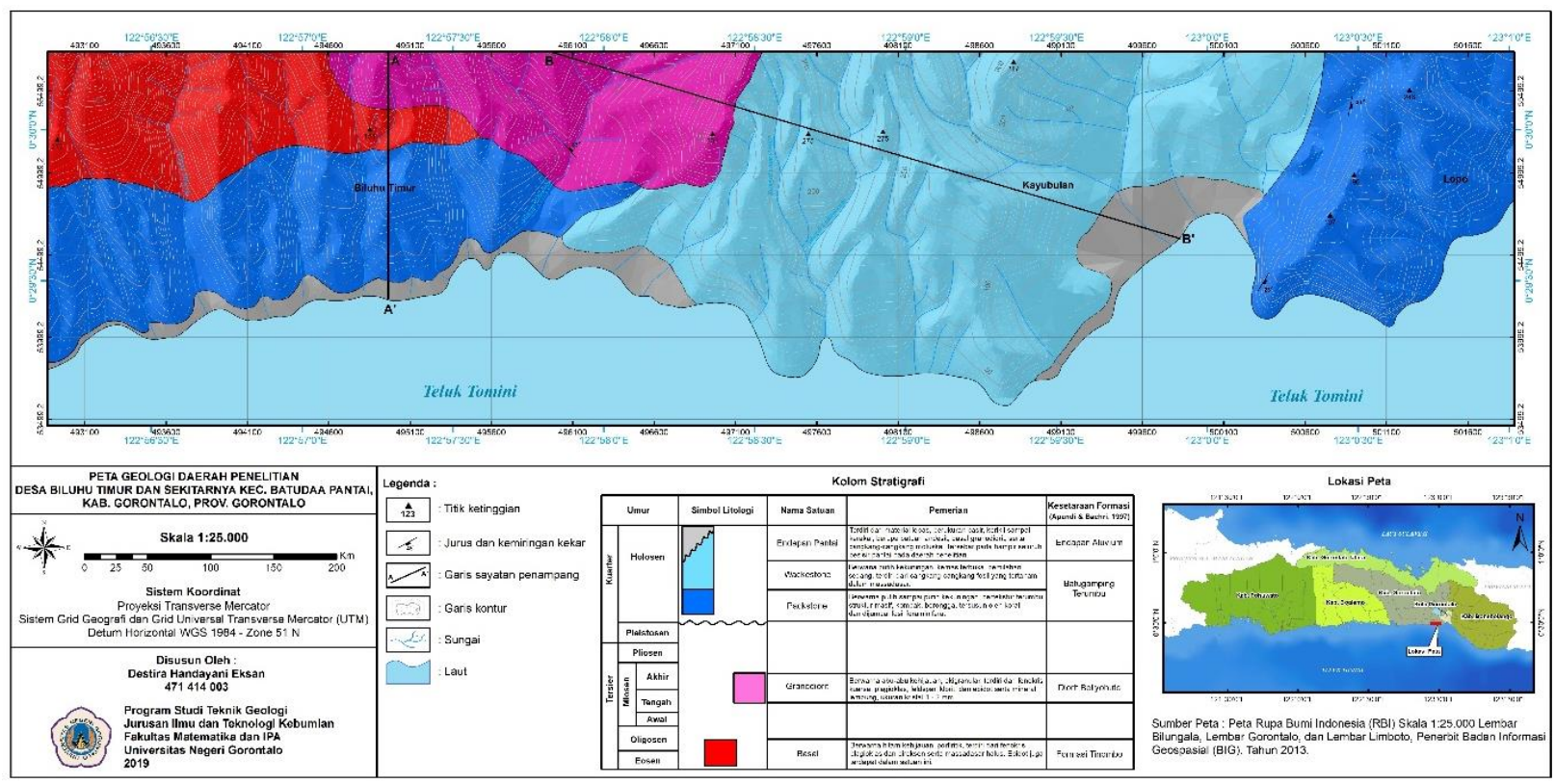

Gambar 8. Peta geologi daerah penelitian

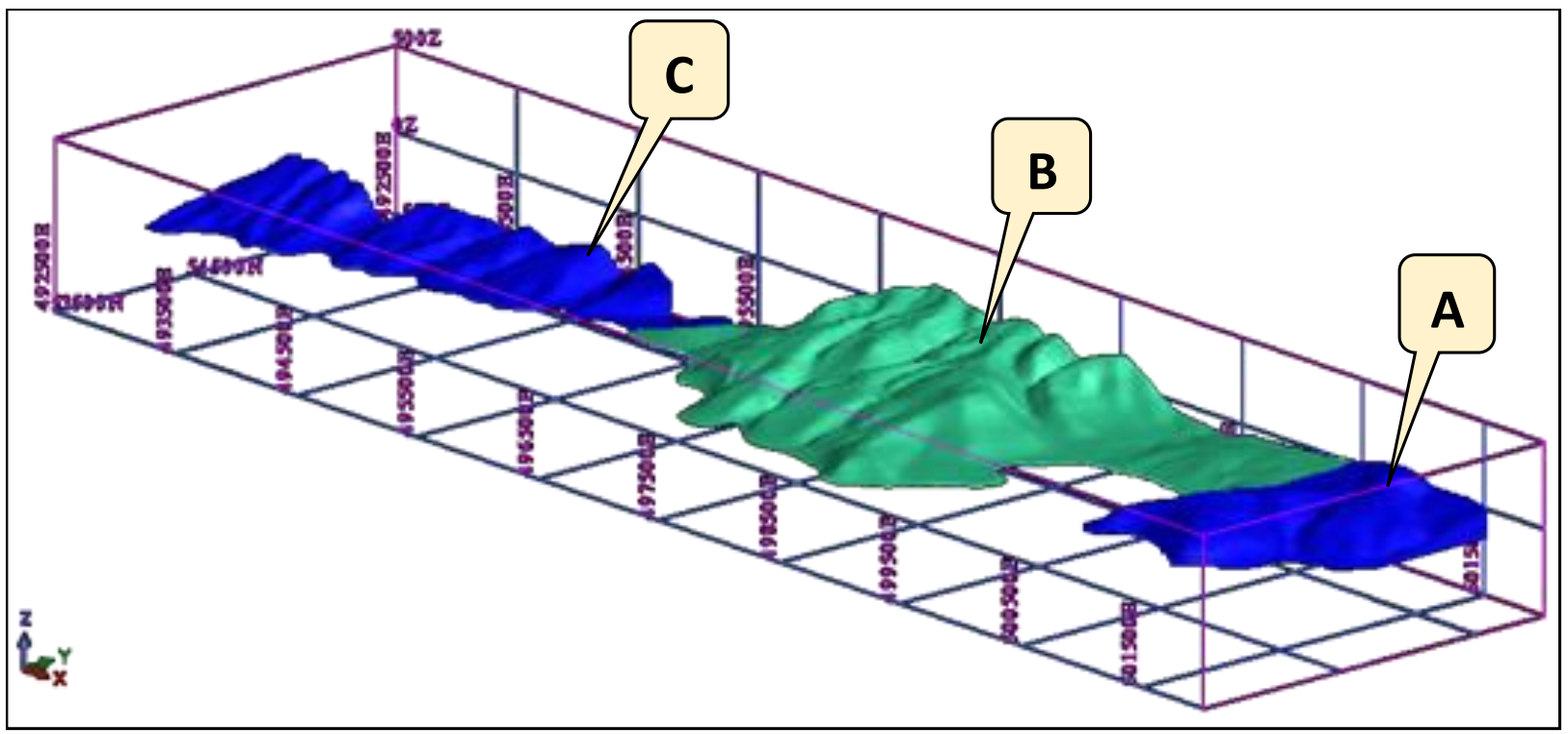

Gambar 9. Model blok potensi batugamping pada daerah penelitian

\subsection{Perhitungan Sumberdaya Batugamping Pada Daerah Penelitian}

Perhitungan sumberdaya batugamping dilakukan menggukan software surpac dengan metode perhitungan total volume berdasarkan nilai kontur terendah hingga nilai kontur tertinggi pada batugamping yang ada pada lokasi penelitian, yang kemudian dikalikan dengan berat jenis batugamping $\left(2,387 \mathrm{ton} / \mathrm{m}^{3}\right)$ untuk mendapatkan total jumlah sumberdaya dalam satuan ton. Blok A memiliki jenis batugamping packstone dengan kadar $\mathrm{CaO}$ sebesar $51.79 \%$ dan $\mathrm{MgO}$ sebesar $1.98 \%$ yang menurut SNI batugamping pada blok ini layak untuk dijadikan bahan baku dalam pembuatan semen. Hasil dari perhitungan sumberdaya blok ini menunjukkan total volume sebesar 423707230 ton. Blok ini ditandai dengan warna biru tua (Gambar 9).

Blok B memiliki jenis batugamping wackstone. Sebagian besar dari blok ini pada pengamatan lapangan sudah banyak dimanfaatkan sebagai lahan perkebunan dan pemukiman masyarakat sekitar. Kandungan $\mathrm{CaO}$ yang rendah dan kandungan $\mathrm{MgO}$-nya yang tinggi masing - masing yaitu $4.92 \%$ untuk $\mathrm{CaO}$ dan $5.28 \%$ untuk $\mathrm{MgO}$, membuat blok ini tidak layak untuk dapat dijadikan sebagai bahan baku dalam pembuatan semen. Total volume blok ini sebesar 729263008 ton yang ditandai dengan warna hijau toska (Gambar 9). Blok C memiliki jenis batugamping packstone dengan kandungan $\mathrm{CaO}$ sebesar 52.85\% dan $\mathrm{MgO}$ sebesar $0.97 \%$ yang menurut SNI layak untuk dijadikan sebagai bahan baku dalam pembuatan semen. Blok ini menunjukkan total volume sejumlah 539883150 ton. Blok ini ditandai dengan warna biru tua (Gambar 9). 
Pemanfaatan yang disarankan dan sesuai dengan kualitas batugamping didaerah penelitian adalah sebagai bahan baku Semen Portland Tipe I. Hasil dari penjumlahan sumberdaya pada blok A ditambah dengan jumlah sumberdaya pada blok $\mathrm{C}$ yang merupakan batugamping yang layak dijadikan sebagai bahan baku pembuatan semen hasilnya yaitu, $423707230+539883150=963590380$ ton, sedangkan total jumlah volume batugamping yang tidak memenuhi persyaratan minimum sebagai bahan baku semen yaitu sebesar 729263008 ton.

\section{Kesimpulan}

Secara geologi, daerah penelitian dapat dibagi menjadi lima satuan geomorfologi yaitu satuan perbukitan vulkanik Biluhu Timur, satuan dataran marin Batudaa Pantai, satuan perbukitan denudasional Batudaa Pantai dan satuan dataran Denudasioal Kayubulan, disusun oleh litologi berupa satuan basal berumur Eosen, satuan granodiorit berumur Miosen, dan satuan batugamping terumbu (wackestone dan packstone) yang mendominasi serta endapan pantai berumur Holosen. Struktur geologi yang berkembang berupa jaringan kekar yang relatif berarah utara-selatan.

Batugamping pada daerah penelitian yang memenuhi persyaratan untuk dapat digunakan sebagai bahan baku semen dibagi atas dua blok, yakni pada blok A dan blok $\mathrm{C}$ yang masing-masing memiliki kandungan $\mathrm{CaO} 51.79 \%$ dan $\mathrm{MgO} 1.98 \%$ untuk blok $\mathrm{A}$ dan $\mathrm{CaO} 52.85 \%$ dan $\mathrm{MgO} 0.97 \%$ untuk blok C. Sedangkan pada blok $\mathrm{B}$ memiliki kandungan $\mathrm{CaO} 4.92 \%$ dan $\mathrm{MgO} 5.28 \%$ yang tidak memenuhi persyaratan sebagai bahan baku semen menurut SNI. Pemanfaatan yang disarankan dan sesuai dengan kualitas batugamping didaerah penelitian adalah sebagai bahan baku Semen Portland Tipe I.

Hasil dari penjumlahan sumberdaya pada blok A ditambah dengan jumlah sumberdaya pada blok C, jadi hasilnya yaitu $423707230+539883150=963590380$ ton untuk batugamping yang berpotensi sebagai bahan baku semen, sedangkan total jumlah volume batugamping yang tidak memenuhi persyaratan minimum sebagai bahan baku semen yaitu 729263008 ton.

\section{Referensi}

ASTM-C150. 2014. Standart Specification of Portland Cement. United States.

[BPS] Badan Pusat Statistik. 2018. Batudaa Pantai Dalam Angka 2018. Provinsi Gorontalo.

[BSN] Badan Standarisasi Nasional. 2010. SNI 7574:2010 Penentuan Kadar CaO, $\mathrm{MgO}, \mathrm{SiO}_{2}, \mathrm{Al}_{2} \mathrm{O}_{3}, \mathrm{Fe}_{2} \mathrm{O}_{3}$, $\mathrm{MnO}, \mathrm{Na}_{2} \mathrm{O}, \mathrm{K}_{2} \mathrm{O}$ dan LOI Dalam Contoh Batugamping, Kalsit, Dolomit, dan Marmer. Bandung: Badan Standarisari Nasional.

Dunham, R, J., 1962, Clasification of Carbonates rocks according to Deposition Texture, p108 - 121.

Sukandarrumidi, 1999. Bahan Galian Industri, Gadjah Mada University. Yogyakarta.

Sukhyar, R., Calvin, Prima, Sabtanto, Kusdarto.2012.Batugamping di Indonesia.Kementrian Energi dan Sumberdaya Mineral, Indonesia.

Van Zuidam, R, A. 1985. Aerial Photo Interpretation In Terrain Analysis and Geomorphologic Mapping. ITC, Smits Publ. Enschede, The Hagu Netherlands. 